\title{
Review of Cerebral Microangiopathy and Alzheimer's Disease: Relation between White Matter Hyperintensities and Microbleeds
}

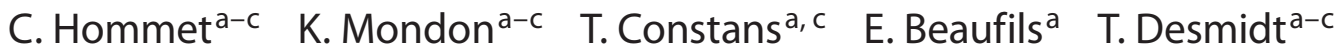 \\ V. Camus ${ }^{a-c}$ J.P. Cottier ${ }^{b-d}$ \\ a Médecine Interne Gériatrique et CMRR, Hôpital Bretonneau, CHRU Tours, b Inserm U 930, \\ 'Université François Rabelais Tours, and d Neuroradiologie, Hôpital Bretonneau, CHRU Tours, Tours, France
}

\section{Key Words}

Elderly subjects $\cdot$ Alzheimer's disease $\cdot$ White matter hyperintensities $\cdot$ Microbleeds $\cdot$ Affective symptoms • Cognition

\begin{abstract}
Although Alzheimer's disease (AD) is basically considered to be a neurodegenerative disorder, cerebrovascular disease is also involved. The role of vascular risk factors and vascular disease in the progression of $A D$ remains incompletely understood. With the development of brain MRI, it is now possible to detect small-vessel disease, whose prevalence and severity increase with age. The first types of small-vessel disease to be described were white matter hyperintensities (WMHs). More recently, small areas of signal loss on $\mathrm{T}_{2}{ }^{*}$ weighted images, also called microbleeds (MBs), have been reported. Cerebral MBs are focal deposits of hemosiderin that indicate prior microhemorrhages around small vessels, related to either ruptured atherosclerotic microvessels or amyloid angiopathy. Consequently, using brain MRI for the detection of microangiopathy may prove useful to improve our understanding of the impact of the vascular burden in $A D$ pathology. The relationship between microangiopathy
\end{abstract}

and the clinical course of AD or the conversion of mild cognitive impairment to $A D$ remains questionable in terms of cognitive or affective symptoms, particularly if we consider MBs.

Copyright $\odot 2012$ S. Karger AG, Basel

The aim of this review was to provide a perspective of brain MRI in the detection of microangiopathy, including both white matter hyperintensities (WMHs) and microbleeds (MBs), and their clinical consequences in the elderly by improving our understanding of the consequences of microangiopathy in Alzheimer's disease (AD), considering both cognitive and noncognitive (affective) symptoms. A better understanding of the role of microangiopathy in $\mathrm{AD}$ could contribute to the development of future therapeutic and preventive modalities.

$\mathrm{AD}$ is characterized by a progressive decline in memory associated with other cognitive deficits: judgment, abstraction, language, attention and visuoconstructive abilities. The current diagnostic criteria for AD require cognitive decline in memory and at least one other cognitive domain, both of which have been present for 6 months or more and have resulted in a significant impact on the patient's activities of daily living [1]. These cognitive 
symptoms are associated with other noncognitive symptoms, particularly behavioral, affective symptoms and personality changes [2]. Behavioral and psychological symptoms have been shown to be associated with a poorer prognosis, to increase caregiver burden [2-5] and to be associated with incident mild cognitive impairment (MCI) and/or AD [6, 7]. Among these symptoms, depression and apathy are associated with an increased risk of developing AD [8-11]. All of these functional losses lead to a significant impairment in the activities of daily living. Recently, clinicians have become increasingly interested in the diagnosis of $\mathrm{AD}$ at its prodromal stage, which has also been described as MCI [12-14], in the hope of developing future, disease-modifying therapies.

$\mathrm{AD}$ is considered to be an essentially neurodegenerative disorder. However, cerebrovascular disease is involved as well $[15,16]$. With the development of brain MRI, we can now detect small-vessel disease: WMHs/leukoaraiosis (LA), and MBs, which are all commonly found on brain MRIs in elderly and AD subjects [17]. The localization and quantification of microangiopathy with MRI are based on normal sequences, and no contrast material is required. The first to be reported were WMHs. WMHs are frequently present and were quickly considered to be markers of brain aging. However, there are increasing data suggesting that WMHs may have consequences in aged-related disabilities and play a role in the clinical course of $\mathrm{AD}$, notably in cognitive and affective symptoms. There has also been increased interest in the role played by MBs due to the development of new brain MRI sequences.

The aim of this paper was to investigate the consequences of microangiopathy on the clinical course of $\mathrm{AD}$ by using $\mathrm{WMH}$ and, more recently, $\mathrm{MB}$ data in elderly patients. Our research selected studies published between 1990 and 2010 from the MEDLINE Database using the search terms: 'white matter hyperintensities' or 'microbleeds and cognition', 'affective symptoms', 'depression' and 'AD'. A better understanding the role of microangiopathy may lead to new therapeutic and preventive modalities in $\mathrm{AD}$ patients in the future.

\section{Vascular Factors in AD}

Data from epidemiological studies indicate that elderly patients, especially those with vascular risk factors and in particular diabetes, hypertension or hypercholesterolemia, have an increased of developing AD [18-27] and cognitive decline. A history of stroke is also associated with an increased risk of developing AD [28].
However, the role of vascular disease in the progression of $\mathrm{AD}$ or the conversion of $\mathrm{CI}$ to $\mathrm{AD}$ remains unknown. Some authors have failed to find any association between vascular risk factors and the rate of cognitive decline in $\mathrm{AD}$ subjects during follow-up periods of 1 year [29], 18 months [30], 2 years [31] or even 3 years [32].

In contrast, other authors have reported a faster cognitive decline in $\mathrm{AD}$ patients with hypertension, angina or atrial fibrillation than in AD patients without these disorders, during a 3 -year follow-up [33, 34]. Moreover, the cognitive decline is faster in subjects who have a history of stroke [32]. Another argument in favor of the role of vascular risk factors in the clinical course of $\mathrm{AD}$ was reported by Deschaintre et al. [35]. They described a slower decline in MMSE scores in AD patients who had no cerebrovascular disease as opposed to subjects under treatment for vascular risk factors. The role played by cerebrovascular disease in cognitive impairment has not been completely elucidated [26]. In fact, other factors, like asymptomatic stroke, genetic factors particularly ApoE4 genotype (ApoE $\varepsilon 4$ ) [36] and microangiopathy, may be involved.

\section{White Matter Hyperintensities on Brain MRI: Not New but Still Debated}

Progress in brain imaging, particularly in CT and MRI scans, led to the description of changes in white matter in elderly subjects. Their prevalence varies from 10 to $94 \%$ [37]. The term leukoaraiosis was proposed by Hachinski et al. [38] to describe the radiological rarefaction of white matter. It refers to white matter abnormalities such as large hypodensities on CT scans and WMHs on $\mathrm{T}_{2}$-weighted MRI images (fig. 1), whose prevalence and severity increase with age [38-41].

Different methods can be used to measure the extent of WMHs and include visual rating to fully computerized techniques. Visual rating of WMHs is easy, and several scales, such as the scales of Fazekas et al. [42], Scheltens et al. [43] and the Age-Related White Matter Changes (ARWMC) scale [44], are available with good reproducibility. For example, the ARWMC scale, a modified version of the visual scale of Fazekas et al. [42], classifies periventricular and deep WMHs into three categories (low, moderate and severe) in six regions (frontal, parietal, occipital, temporal, basal ganglia/thalamus and infratentorial). Most volumetric studies use supervised semi-automated techniques that may provide more information on location and size, as well as continuous data, 
1

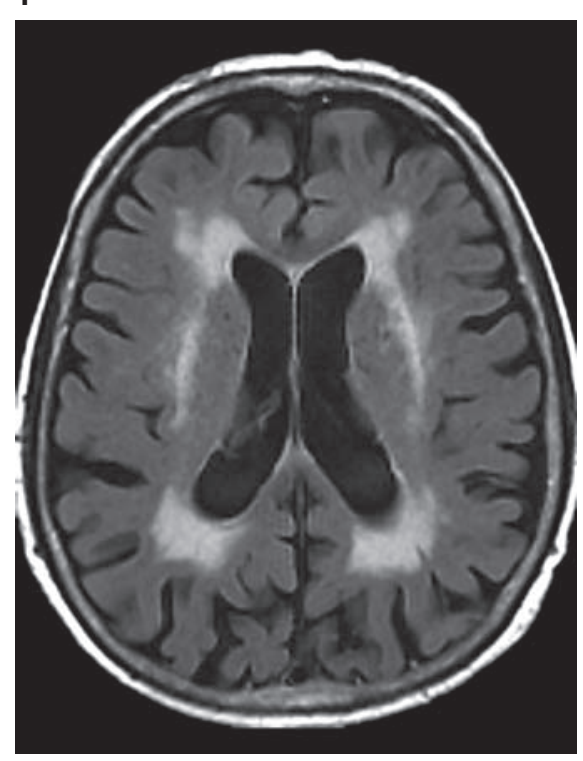

2

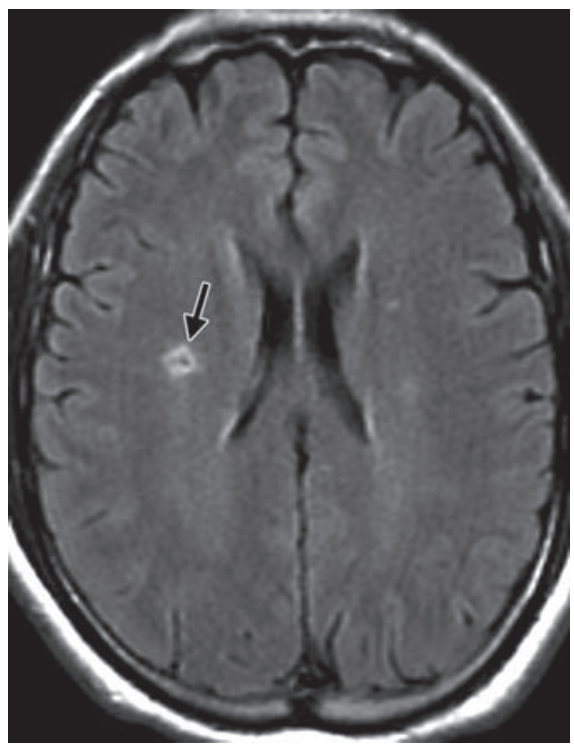

Fig. 1. LA. Axial $T_{2}$ FLAIR-weighted $M R$ image showing white matter intensities mainly around the ventral and occipital horns of the lateral ventricles.

Fig. 2. Lacune. Axial $\mathrm{T}_{2}$ FLAIR-weighted MR image showing a lacuna in the right corona radiata: nodular hyposignal surrounded by a hyperintense rim (arrow). hyperintense rim on fluid attenuation inversion recovery (FLAIR) images (fig. 2). On histological examination, MRI lacunas were found to correspond to irregular cavitation with scattered fat-laden macrophages, which can be accompanied by surrounding reactive gliosis and myelin and axonal loss. The most frequently reported cause of lacunas is acute arteriolar occlusion by arteriosclerosis/ thrombosis. Other possible mechanisms include thromboembolism, generalized hypoxia or tissue damage caused by extravasated toxic serum proteins due to bloodbrain barrier leakage [53].

\section{WMHs and Age-Related Disabilities}

In elderly subjects, WMHs may be considered as a normal aging phenomenon. However, from the clinical point of view, WMHs have been associated with cognitive, motor and neuropsychiatric symptoms.

In cross-sectional studies, white matter changes are associated with (1) cognitive impairment: impaired recall and speed processing, a dysexecutive syndrome [54-57] and difficulties in working memory [55, 58-61]; (2) agerelated motor deficits: gait apraxia, impaired balance in walking, increased risk of falls [57, 62-68], severe urinary incontinence [56], or (3) global functioning [39, 56, 69]. They have also been associated with neuropsychiatric symptoms, particularly depressive symptoms $[68,70,71]$.

In elderly subjects, white matter changes are also associated with an increased risk of dementia [72-74]. Prospective studies have confirmed these results. The multicenter Leukoaraiosis and Disability Study (LADIS) is 
a prospective multinational European project investigating the impact of white matter changes on the transition to disability in the elderly [75]. This study began in 2000 and included subjects aged 65-84 years, who were independent in activities of daily living at the time of enrollment in the study. On MRI, they had different degrees of severity in white matter lesions $(1.5 \mathrm{~T})$ measured with the scale of Fazekas et al. [42]. The subjects were evaluated at baseline and yearly for a period of 3 years, with repeated clinical assessment and a final MRI. The rate of functional decline was different according to the severity of the white matter lesion at 1 and 3 years follow-up: there was a 2 -fold increase in the risk of transition to disability or death in the severe group compared with the mild group following adjustment for confounding factors [39, 76]. In a recent study from the LADIS, age-related white matter changes and vascular risk factors were predictive of cognitive decline [77]. In elderly subjects living independently, white matter changes and diabetes at baseline were independent predictors of cognitive decline (dementia and no dementia) after controlling for medial temporal atrophy, age and educational level.

The 3-C study is another multicenter cohort study conducted in three French cities aimed at estimating cognitive impairment and the risk of dementia attributable to vascular factors. A total of 9,294 subjects were enrolled between 1996 and 2001. The MRI studies evaluated the relationship between brain MRI markers (white matter lesions, silent brain infarct and hippocampal volume) and longitudinal changes in cognition during the 4-year follow-up period. The risk of dementia and the rate of cognitive decline significantly increased in subjects with more voluminous white matter lesions and smaller hippocampal volumes, suggesting a cumulative effect [78].

The white matter changes also have consequences on neuropsychiatric symptoms. Depression in individuals older than 65 years is strongly associated with a vascular component leading to the concept of vascular depression [79-84]. The hypothesis is that cerebrovascular disease, especially white matter lesions, may contribute to the pathogenesis of depression, predisposing or precipitating depressive symptoms in elderly people, by disrupting neural circuits or fiber tracts connecting frontal and subcortical regions $[81,85,86]$. According to the cross-sectional analysis by Godin et al. [68], subjects with lateonset major depression have more voluminous white matter lesions than subjects with smaller lesions.

In the LADIS study $[87,88]$, the baseline severity of white matter changes independently predicted the development of depressive symptoms at 2 and 3 years of follow- up and incident depression. In addition, WMHs are predictive of the progression of depressive symptoms [89]. The study by Godin et al. [68] was the first longitudinal study to investigate the relationship between white matter lesion volumes, white matter volume changes, and depression in the elderly. The progression of white matter lesions during the 4-year follow-up period was faster in subjects with late major depression at baseline. In addition, more voluminous baseline white matter lesions were associated with an increased risk of developing depression during life in subjects who were free of depression. In contrast, in a 3-year longitudinal study, Versluis et al. [90] did not find any relationship between WMHs and depressive symptoms in elderly subjects.

However, the physiopathological and anatomical correlates of late-onset depression is complex [91] even if the role of white matter lesions has been reported. Recent clinicopathological studies comparing elderly nondemented subjects with late-onset depression with healthy controls, using a semiquantitative assessment of microangiopathy (white matter lesions, microinfarcts and gliosis) reported that the frequency of all the lesions did not differ between late-onset depression and controls [92, 93]. Moreover, clinicopathological correlates of late-onset depression, Alzheimer-type pathology and microangiopathy are questionable, and need more neuropathological studies and clinical longitudinal studies using biomarkers of amyloid load: molecular PET imaging and CSF concentration of $A \beta$ peptide $(A \beta 42)$, total tau (T-tau) and phosphorylated tau (p-Tau).

\section{WMHs: What Are Their Consequences for the Clinical Course of $A D$ ?}

At autopsy, deep white matter changes are found in more than $60 \%$ of patients with AD [94]. WMHs are also common in MCI [95-97]. We know that white matter changes are associated with cognitive decline, but the clinical significance of microangiopathy in $\mathrm{AD}$ is more complex, especially considering its role in the clinical course of the disease.

A few longitudinal studies have examined the role of microangiopathy in the risk of progression from MCI to $\mathrm{AD}$, but the results have been contradictory $[26,54,96$, $98,99]$. Some researchers failed to find any association between white matter changes and the risk of progression from $\mathrm{MCI}$ to $\mathrm{AD}[26,54,100]$, whereas others did in fact find a relationship between white matter changes and progression to AD in MCI patients $[96,98]$. Some characteristics of WMHs need to be studied further: white matter volumes, localization (periventricular or total) 
and rate of progression. Progression in total and periventricular WMH volumes predicts an increase in persistent cognitive impairment when compared to the baseline WMH burden [101]. In the longitudinal DESCRIPTA study (European Multicenter Clinic-Based Memory), Jacobs et al. [102] studied the influence of the location of WMHs on the executive functions in MCI during a 3-year period and found that parietal WMHs were associated with a decline in executive functions in MCI. In the ADNI study (Alzheimer Disease Neuroimaging Initiative) [103], a greater $\mathrm{WMH}$ volume at baseline and 1-year follow-up was associated with greater cognitive impairment at baseline and at follow-up.

Data investigating the consequences of WMHs on the clinical course of the affective symptoms of AD are lacking. Staekenborg et al. [5] studied the differences in the prevalence of behavioral and psychological symptoms in $\mathrm{AD}$ according to the prevalence of WMHs and found no difference in prevalence according to white matter lesions. In a cross-sectional study, Kumar et al. [104] investigated structural brain MRI correlates of depressive symptoms in MCI subjects. They failed to find any correlation between depression severity and MRI measures (WMH load and hippocampal volume), but the lack of association may be due to the relatively young age of the patients in the MCI group (60-64 years). Recent data in AD suggest that vascular disease could affect cognition through effects on subcortical connections and white matter changes but may also exacerbate cortical atrophy, suggesting a potential synergistic effect [105]. Further prospective clinicopathological studies are required to elucidate the relationship between microangiopathy, cognition and affective symptoms.

\section{MBs: New Protagonists in the Microangiopathy Debate}

Appropriate magnetic resonance $\mathrm{T}_{2}{ }^{*}$-weighted gradient-echo can detect hemorrhagic manifestations of microangiopathy (MBs) $[106,107]$. MBs are small, round, hypointense foci on $\mathrm{T}_{2}{ }^{*}$ (or gradient echo)-weighted MRI scans (fig. 3). These small areas of signal loss on $\mathrm{T}_{2}{ }^{*}$ weighted images correspond to hemosiderin deposits surrounding small vessels. Histopathological studies have confirmed that MBs are linked to either disrupted atheroscerotic microvessels [108-110] or amyloid angiopathy [111-113].

In the literature, authors varied in their classifications of the distribution of MBs; they also varied in their de-

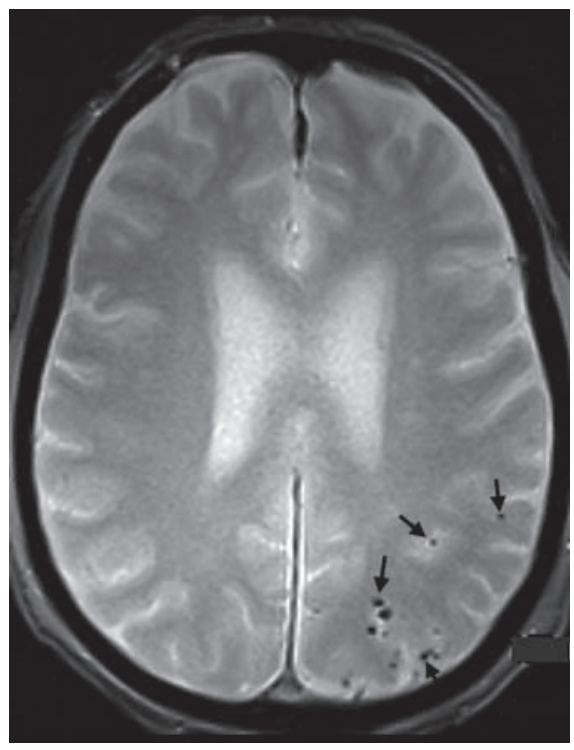

Fig. 3. Microbleeds. Axial $\mathrm{T}_{2}{ }^{*} \mathrm{MR}$ image showing numerous cortical hyposignal foci in the left parietal area (arrows).

scription of either the presence or the mean number of MBs per location and used different grading systems [114, 115]. None of these classifications of MB distribution has been validated. In most studies, their number and location are analyzed visually and distinguished by their number into four groups $[112,116,117]$ : no MBs, $1-5$ MBs, 6-10 MBs and more than 11 MBs.

MBs are frequently associated with ischemic cerebral changes, such as lacunar lesions and white matter changes [106]. The prevalence of MBs in apparently healthy subjects is estimated to be $5 \%$, but MBs can be present in $34 \%$ of patients who have had ischemic strokes and in $60 \%$ of individuals who have had nontraumatic intracerebral hemorrhages [109]. The prevalence increases with age, reaching $13 \%$ in subjects older than 75 years [107] and $17 \%$ in a large cohort of patients followed in a memory clinic [109]. MBs are associated with hypertension and diabetes [109]. When they are associated with hypertension, the most frequent locations are the basal ganglia, thalamus, brainstem and cerebellum [111], and lobar (mainly in the occipital lobe) when they are associated with amyloid angiopathy [118].

The potential cognitive effects of MBs in elderly subjects remain relatively unexplored. In the general population, studies on the cognitive consequences of MBs are lacking and the few results published have been conflicting. Cordonnier et al. [114], in a hospital-based study of 772 subjects followed in a memory clinic, found no rela- 
tionship between MBs and MMSE scores. In contrast, Yakushiji et al. [110] reported that MBs are associated with global cognitive dysfunction (lower scores on the MMSE), independently of coexisting vascular risk factors. The consequences of MBs for selected cognitive domains have received little attention, and the published studies mainly looked at executive functions $[119,120]$. A correlation between cognitive decline and the burden of MBs in patients with intracerebral hemorrhages has been demonstrated [121]. MBs are particularly frequent in subjects with subcortical vascular dementia and mainly concern all the cognitive domains with the exception of the language functions $[120,122]$. Few data are available on the effects of cerebral MBs on psychiatric symptoms and are restricted to poststroke subjects. Tang et al. [123] reported that lobar MBs were associated with a higher risk of poststroke depression, emotional lability [124] and that MBs contribute to the severity of poststroke depression [125].

The relationship between MBs and neuropsychological testing in $\mathrm{AD}$ patients has received but little attention as well. Pettersen et al. [118] failed to demonstrate any association with neuropsychological performances, but most of the AD patients they studied had only one or a few MBs. The available data on MBs suggest that we need to take into account whether or not they are present and the number of MBs when they are. Goos et al. [115] in a retrospective study on $63 \mathrm{AD}$ subjects investigated the association between MBs and neuropsychological data and CSF biomarkers. They compared two groups of AD subjects according to the number of MBs they had: AD patients with multiple MBs (more than 8 ) and AD patients without MBs. The AD group with multiple MBs had lower MMSE scores than those without MBs and lower performance on animal (verbal) fluency, visual-associated test object naming and digit span (forward and backward) than the group without multiple MBs. They also had more severe WMHs and lower A $\beta 42$ CSF levels than patients without MBs and no more atrophy. In MCI subjects, MBs are predictive of cognitive decline [126, 127] and have been found to be a risk factor for progression from MCI (without any clinical data on the subtype) to non-Alzheimer dementia [100].

Unfortunately, there are no data on the relationship between MBs and affective symptoms in $\mathrm{AD}$ or MCI patients. Moreover, many questions remain unresolved: should we consider MBs to be a new marker for aging? Do they have any clinical consequences? We probably need to consider not only the presence of MBs but equally their number. The detection of MBs could have practical con- sequences for the diagnosis of $\mathrm{AD}$ and perhaps for understanding the physiopathology of the disease and, consequently, new therapeutic modalities.

\section{Discussion and Future Directions for Study}

MRI evidence of small-vessel disease (or microangiopathy) is commonly found on the brain MRIs of elderly subjects and has rapidly been considered a brain marker of aging. However, there are increasing data suggesting that microangiopathy has consequences for aged-related disabilities and that it potentially plays a role in the clinical progression of the cognitive and affective symptoms of AD subjects. MBs, lacunar lesions and WMHs/LA are frequently associated and may be considered to predict the severity of cerebral microangiopathy [106], lacunas representing the final pathway in the spectrum of smallvessel disease [57].

The influence of microangiopathy on the clinical course can be seen from two main perspectives: on the one hand, the severity of microangiopathy, and on the other hand, the neuropathological correlates underlying microangiopathy [128]. In fact, some recent reports have shown that neuroinflammation may be involved [37, 129-131]. Postmortem studies of AD brains demonstrated the presence of acute-phase inflammatory reactions in senile plaques and neurofibrillary tangles and their implication in neuronal death [132-135]. This inflammatory response is mainly orchestrated by resident cells, such as activated microglia, surrounding the senile plaques. Various human and animal studies demonstrated the implication of neuroinflammation in amyloidogenic processing $[136,137]$. Moreover, the relationship between microangiopathy and amyloid burden remains unresolved and could possibly be elucidated with molecular PET imaging. In fact, neuro-inflammation may be assessed in vivo by PET imaging using TSPO (translocator protein)-specific ligands which were formerly known as the peripheral benzodiazepine receptor. Molecular imaging of neuro-inflammation should contribute to our understanding of the physiopathology of white matter lesions and their clinical correlations $[138,139]$. Some AD subjects seem to have just one or only a few MBs, without measurable clinical effects, contrasting with other $\mathrm{AD}$ subjects with a more severe MB burden. But we do not know whether or not MBs reflect a distinct pathological subgroup of AD subjects.

The development of diagnostic biomarkers in AD may help to understand the neuropathological correlates of 
WML/MBs and AD pathology in vivo [14]: amyloid burden by PET using $\left[{ }^{11} \mathrm{C}\right]$-Pittsburgh compound $\mathrm{B}\left(\left[{ }^{11} \mathrm{C}\right]-\right.$ PIB) or other radioligands, such as $\left[{ }^{18} \mathrm{~F}\right]$-AV45 [140], CSF concentration of $A \beta 42$, total Tau (T Tau) and phosphorylated Tau ( $\mathrm{p} \mathrm{Tau}$ ), hippocampal volume (MRI), metabolic changes with PET using 2-deoxy-2-[ $\left.{ }^{[8} \mathrm{F}\right]$ fluoro-D-glucose ([18F]-FDG).

No studies have addressed WMH and amyloid load using $\left[{ }^{11} \mathrm{C}\right] \mathrm{PIB}$. The association between WML and CSF levels of $A \beta 1-42$, Tau and $P$ Tau levels were studied in cerebral autosomal dominant arteriopathy with subcortical infarcts leukoencephalopathy (CADASIL), a model of pure subcortical dementia [141]. CSF A $\beta$ 1-42 levels were significantly lower in CADASIL subjects than in controls whereas CSF T Tau and P Tau levels did not differ between the two groups. An additional study [142] evaluated the relationship between WML and CSF A $\beta$ 1-42 in 127 consecutive subjects with subjective memory impairment (mean MMS score 24 with no more details about cognition) and reported a link between WML and low CSF A $\beta$. In contrast, in nondemented elderly subjects with WML (from the LADIS study), Jonsson et al. [143] reported no association between WML and AD biomarkers (P Tau and $A \beta 1-42)$.

The relationship between MBs and $\beta$-amyloid deposition, studied using PIB, was evaluated in cerebral amyloid angiopathy [144]. PIB retention was increased at the sites of cerebral amyloid angiopathy-related MBS and declined with increasing distance from the MBs. In a retrospective study, Goos et al. [115] investigated the relationship between MBs and CSF biomarkers in $\mathrm{AD}$ and showed that $\mathrm{AD}$ with multiple $\mathrm{MBs}(\geq 8 \mathrm{MBs})$ had lower CSF amyloid $\beta$ 1-42 levels than patients without MBs, even after adjustment for white matter lesions. The relationship between cerebral glucose metabolism using PET with $\left[{ }^{18} \mathrm{~F}\right]-F D G$ and WML was only studied in cognitively intact elderly subjects. The severity of WML (particularly periventricular WML) was associated with a decline in global and regional cerebral glucose metabolism $[145,146]$.

A few studies have assessed the relationships between the MR biomarkers of small-vessel disease (WMHs, MBs) and the MR biomarker of AD (hippocampal atrophy) $[100,115,147-149]$. Firstly, it is important to note that white matter lesions, cortical MBs and hippocampal atrophy are associated with each other and with age, and that these changes are affected by the aging process independently of any cerebrovascular risk factor [150]. Van der Flier et al. [147] showed that after adjustment for age, a combination of hippocampal atrophy and severe WMH was associated with a more than fourfold increase in the frequency of MCI in a large group of nondisabled elderly subjects. In contrast, MCIs were not more frequent in the groups of patients with a single MRI abnormality (either medial temporal atrophy or severe WMHs). These results suggest the combined involvement of both an Alzheimer-type disorder and vascular pathology in the earliest stages of cognitive decline. Microvascular dysfunction caused by cerebral amyloid angiopathy could lead to both hippocampal atrophy and white matter lesions in $\mathrm{AD}$ [148]. Because amyloid angiopathy is also one of the major features of normal aging [151], it suggests that simultaneous progression of hippocampal atrophy and white matter lesions may reflect the progression of amyloid angiopathy in elderly persons without major cerebrovascular risk factors.

The presence of cortical infarctions also increased the risk of dementia in patients with hippocampal atrophy, demonstrating that patients with MCI progress to dementia faster if they have cortical infarctions along with findings associated with AD on MRI [149].

In a cohort of AD patients with multiple $(\geq 8) \mathrm{MBs}$ on $\mathrm{T}_{2}{ }^{*}$-weighted MRI and matched for age, atrophy (medial temporal lobe or global cortical) was not related to the presence of MBs [115], but an interaction between MBs and cortical atrophy was found to result in a 6-fold increased risk of death for patients with severe cortical atrophy and multiple MBs in comparison to subjects without cortical atrophy and MBs.

Consequently, biomarkers contribute to our understanding of the pathophysiology of WML/MBs. In contrast to WML, cerebral MBs seem to share features with amyloid angiopathy.

A better understanding of the pathological basis of MRI changes and their consequences on the clinical course of dementia is important from a nosological point of view. In fact, vascular dementia and $\mathrm{AD}$ have generally been considered to be separate disease entities. However, they share common features (like vascular risk factors) and vascular risk factors are also risk factors for white matter changes [77]. Microangiopathy is present in both $\mathrm{AD}$ and vascular dementia, and $\mathrm{WMHs}$ are associated with an increased risk of AD [152] and MCI [54]. Vascular and degenerative processes have complex interactions. Therefore, a better understanding of the role of microangiopathy could suggest that there is in fact a spectrum ranging from pure vascular dementia to pure $\mathrm{AD}$ and including a majority of patients with contributions from both Alzheimer and vascular pathologies [23]. The topography of brain MBs (a corticosubcortical or a 
deep location) could allow us to predict whether dementia is vascular or $\mathrm{AD}$ [153].

Thanks to the development of brain MRI, we are now capable of obtaining a more precise description of microangiopathy lesions. However, microangiopathy, ranging from $\mathrm{WMHs}$ to $\mathrm{MBs}$, is perhaps only the tip of the iceberg. In fact, cortical microinfarcts and mild tissue changes in normal-appearing white matter on $\mathrm{T}_{2}$ weighted images are other expressions of small-vessel disease revealed by postmortem studies, which are not detectable by conventional MRI. These abnormalities could also play an important role in the clinical symptomatology. Future research directions should include the use of newer MR techniques, especially diffusion tensor imaging, magnetization transfer imaging or relaxation time mapping that could help detect white matter injuries at an earlier time point $[127,154-156]$ and to investigate tissue damage that is not visible by conventional structural MRI $\mathrm{T}_{2}$ relaxation time measurements [37].

Many questions concerning MBs have not been answered yet: what is their significance? Do they have sig- nificant clinical consequences for elderly subjects and $\mathrm{AD}$ ? What is the relationship between microangiopathy and neurodegenerative lesions in $\mathrm{AD}$ ? Additional information on their physiopathology may lead to efficient therapeutic modalities and help us define specific subgroups of patients with specific disease processes and a different clinical course, who would benefit from a specific type of management. In the future, neuroimaging using both MRI and molecular imaging should be a major tool to assess the efficacy of preventive and therapeutic measures in the treatment of microangiopathy.

\section{Acknowledgement}

The authors thank Dr. Donald Schwartz, who revised the English.

\section{Disclosure Statement}

The authors have no sponsorship or funding arrangements to disclose relating to the present paper.

\section{References}

1 McKhann G, Drachman D, Folstein M, Katzman R, Price D, Stadlan EM: Clinical diagnosis of Alzheimer's disease: report of the NINCDS-ADRDA Work Group under the auspices of Department of Health and $\mathrm{Hu}-$ man Services Task Force on Alzheimer's Disease. Neurology 1984;34:939-944.

-2 Aalten P, Verhey FR, Boziki M, Bullock R, Byrne EJ, Camus V, Caputo M, Collins D, De Deyn PP, Elina K, et al: Neuropsychiatric syndromes in dementia. Results from the European Alzheimer Disease Consortium. Part I. Dement Geriatr Cogn Disord 2007;24: 457-463.

-3 Eustace A, Coen R, Walsh C, Cunningham CJ, Walsh JB, Coakley D, Lawlor BA: A longitudinal evaluation of behavioural and psychological symptoms of probable Alzheimer's disease. Int J Geriatr Psychiatry 2002; 17:968-973.

-4 Finkel SI, Costa e Silva J, Cohen G, Miller S, Sartorius N: Behavioral and psychological signs and symptoms of dementia: a consensus statement on current knowledge and implications for research and treatment. Int Psychogeriatr 1996;8(suppl 3):497-500.
Staekenborg SS, Gillissen F, Romkes R, Pijnenburg YA, Barkhof F, Scheltens P, van der Flier WM: Behavioural and psychological symptoms are not related to white matter hyperintensities and medial temporal lobe atrophy in Alzheimer's disease. Int J Geriatr Psychiatry 2008;23:387-392.

6 Teng E, Lu PH, Cummings JL: Neuropsychiatric symptoms are associated with progression from mild cognitive impairment to Alzheimer's disease. Dement Geriatr Cogn Disord 2007;24:253-259.

7 Lobo A, Lopez-Anton R, de-la-Camara C, Quintanilla MA, Campayo A, Saz P: Noncognitive psychopathological symptoms associated with incident mild cognitive impairment and dementia, Alzheimer's type. Neurotox Res 2008;14:263-272.

8 Modrego PJ, Ferrandez J: Depression in patients with mild cognitive impairment increases the risk of developing dementia of Alzheimer type: a prospective cohort study Arch Neurol 2004;61:1290-1293.

\$9 Gabryelewicz T, Styczynska M, Luczywek E, Barczak A, Pfeffer A, Androsiuk W, Chodakowska-Zebrowska M, Wasiak B, Peplonska $\mathrm{B}$, Barcikowska M: The rate of conversion of mild cognitive impairment to dementia: predictive role of depression. Int J Geriatr Psychiatry 2007;22:563-567.
10 Copeland MP, Daly E, Hines V, Mastromauro C, Zaitchik D, Gunther J, Albert M: Psychiatric symptomatology and prodromal Alzheimer's disease. Alzheimer Dis Assoc Disord 2003;17:1-8.

$\rightarrow 11$ Apostolova LG, Cummings JL: Neuropsychiatric manifestations in mild cognitive impairment: a systematic review of the literature. Dement Geriatr Cogn Disord 2008;25: 115-126.

12 Dubois B, Feldman HH, Jacova C, Dekosky ST, Barberger-Gateau P, Cummings J, Delacourte A, Galasko D, Gauthier S, Jicha G, et al: Research criteria for the diagnosis of Alzheimer's disease: revising the NINCDSADRDA criteria. Lancet Neurol 2007;6:734746.

$>13$ Petersen RC, Smith GE, Waring SC, Ivnik RJ, Tangalos EG, Kokmen E: Mild cognitive impairment: clinical characterization and outcome. Arch Neurol 1999;56:303-308.

14 Dubois B, Feldman H, Jacova C, Cummings J, Dekosky ST, Barberger-Gateau P: Revising the definition of Alzheimer's disease: a new lexicon. Lancet Neurol 2010;9:1118-1127.
Hommet/Mondon/Constans/Beaufils/ Desmidt/Camus/Cottier 
15 MRC, CFAS: Pathological correlates of lateonset dementia in a multicentre, community-based population in England and Wales. Neuropathology Group of the Medical Research Council Cognitive Function and Ageing Study (MRC CFAS). Lancet 2001;357: 169-175.

-16 Schmidt R, Ropele S, Enzinger C, Petrovic K, Smith S, Schmidt H, Matthews PM, Fazekas F: White matter lesion progression, brain atrophy, and cognitive decline: the Austrian stroke prevention study. Ann Neurol 2005; 58:610-616

17 Pantoni L: Cerebral small vessel disease: from pathogenesis and clinical characteristics to therapeutic challenges. Lancet Neurol 2010;9:689-701.

- 18 Ott A, Stolk RP, Hofman A, van Harskamp F, Grobbee DE, Breteler MM: Association of diabetes mellitus and dementia: the Rotterdam Study. Diabetologia 1996;39:1392-1397.

- 19 Kivipelto M, Helkala EL, Laakso MP, Hanninen T, Hallikainen M, Alhainen K, Soininen $\mathrm{H}$, Tuomilehto J, Nissinen A: Midlife vascular risk factors and Alzheimer's disease in later life: longitudinal, population based study. BMJ 2001;322:1447-1451.

- 20 Hofman A, Ott A, Breteler MM, Bots ML, Slooter AJ, van Harskamp F, van Duijn CN, Van Broeckhoven C, Grobbee DE: Atherosclerosis, apolipoprotein E, and prevalence of dementia and Alzheimer's disease in the Rotterdam Study. Lancet 1997;349:151-154.

-21 Skoog I, Lernfelt B, Landahl S, Palmertz B, Andreasson LA, Nilsson L, Persson G, Oden A, Svanborg A: 15-year longitudinal study of blood pressure and dementia. Lancet 1996; 347:1141-1145.

22 Chui H, Skoog I: Advances in vascular cognitive impairment 2005. Stroke 2006;37:323325.

23 Viswanathan A, Rocca WA, Tzourio C: Vascular risk factors and dementia: how to move forward? Neurology 2009;72:368-374.

- 24 Biessels GJ, Deary IJ, Ryan CM: Cognition and diabetes: a lifespan perspective. Lancet Neurol 2008;7:184-190.

- 25 Jick H, Zornberg GL, Jick SS, Seshadri S, Drachman DA: Statins and the risk of dementia. Lancet 2000;356:1627-1631.

-26 DeCarli C, Mungas D, Harvey D, Reed B, Weiner M, Chui H, Jagust W: Memory impairment, but not cerebrovascular disease, predicts progression of MCI to dementia. Neurology 2004;63:220-227.

-27 Li G, Shofer JB, Kukull WA, Peskind ER, Tsuang DW, Breitner JC, McCormick W, Bowen JD, Teri L, Schellenberg GD, et al: Serum cholesterol and risk of Alzheimer disease: a community-based cohort study. Neurology 2005;65:1045-1050.

- 28 Vermeer SE, Hollander M, van Dijk EJ, Hofman A, Koudstaal PJ, Breteler MM: Silent brain infarcts and white matter lesions increase stroke risk in the general population: the Rotterdam Scan Study. Stroke 2003;34: 1126-1129.
29 Borroni B, Archetti S, Ferrari M, Cesana BM, Padovani A: Relationship of vascular risk to the progression of Alzheimer disease. Neurology 2007;68:1083-1084, author reply 1084.

30 Regan C, Katona C, Walker Z, Hooper J, Donovan J, Livingston G: Relationship of vascular risk to the progression of Alzheimer disease. Neurology 2006;67:1357-1362.

-31 Abellan van Kan G, Rolland Y, Nourhashemi F, Coley N, Andrieu S, Vellas B: Cardiovascular disease risk factors and progression of Alzheimer's disease. Dement Geriatr Cogn Disord 2009;27:240-246.

32 Bhargava D, Weiner MF, Hynan LS, DiazArrastia R, Lipton AM: Vascular disease and risk factors, rate of progression, and survival in Alzheimer's disease. J Geriatr Psychiatry Neurol 2006;19:78-82.

-33 Mielke MM, Rosenberg PB, Tschanz J, Cook L, Corcoran C, Hayden KM, Norton M, Rabins PV, Green RC, Welsh-Bohmer KA, et al: Vascular factors predict rate of progression in Alzheimer disease. Neurology 2007; 69:1850-1858

34 Helzner EP, Luchsinger JA, Scarmeas N, Cosentino S, Brickman AM, Glymour MM, Stern Y: Contribution of vascular risk factors to the progression in Alzheimer disease. Arch Neurol 2009;66:343-348.

35 Deschaintre Y, Richard F, Leys D, Pasquier F: Treatment of vascular risk factors is associated with slower decline in Alzheimer disease. Neurology 2009;73:674-680.

36 Cosentino S, Scarmeas N, Helzner E, Glymour MM, Brandt J, Albert M, Blacker D, Stern Y: APOE epsilon 4 allele predicts faster cognitive decline in mild Alzheimer disease. Neurology 2008;70:1842-1849.

37 Gouw AA, Seewann A, van der Flier WM Barkhof F, Rozemuller AM, Scheltens P, Geurts JJ: Heterogeneity of small vessel disease: a systematic review of MRI and histopathology correlations. J Neurol Neurosurg Psychiatry 2011;82:126-135.

- 38 Hachinski VC, Potter P, Merskey H: Leukoaraiosis: an ancient term for a new problem. Can J Neurol Sci 1986;13:533-534.

- 39 Inzitari D, Pracucci G, Poggesi A, Carlucci G, Barkhof F, Chabriat H, Erkinjuntti T, Fazekas F, Ferro JM, Hennerici M, et al: Changes in white matter as determinant of global functional decline in older independent outpatients: three year follow-up of LADIS (leukoaraiosis and disability) study cohort. BMJ 2009;339:b2477.

40 Barkhof F, Scheltens P: Imaging of white matter lesions. Cerebrovasc Dis 2002; 13(suppl 2):21-30.

41 Henry-Feugeas MC: MRI of the 'Alzheimer syndrome'. J Neuroradiol 2007;34:220-227.
42 Fazekas F, Chawluk JB, Alavi A, Hurtig HI, Zimmerman RA: MR signal abnormalities at $1.5 \mathrm{~T}$ in Alzheimer's dementia and normal aging. AJR Am J Roentgenol 1987;149:351356.

43 Scheltens P, Barkhof F, Leys D, Pruvo JP, Nauta JJ, Vermersch P, Steinling M, Valk J: A semiquantative rating scale for the assessment of signal hyperintensities on magnetic resonance imaging. J Neurol Sci 1993;114: 7-12.

44 Wahlund LO, Barkhof F, Fazekas F, Bronge L, Augustin M, Sjogren M, Wallin A, Ader H, Leys $\mathrm{D}$, Pantoni $\mathrm{L}$, et al: A new rating scale for age-related white matter changes applicable to MRI and CT. Stroke 2001;32:13181322

45 Gurol ME, Irizarry MC, Smith EE, Raju S, Diaz-Arrastia R, Bottiglieri T, Rosand J, Growdon JH, Greenberg SM: Plasma $\beta$-amyloid and white matter lesions in $\mathrm{AD}, \mathrm{MCI}$, and cerebral amyloid angiopathy. Neurology 2006;66:23-29.

46 Brickman AM, Sneed JR, Provenzano FA, Garcon E, Johnert L, Muraskin J, Yeung LK, Zimmerman ME, Roose SP: Quantitative approaches for assessment of white matter hyperintensities in elderly populations. Psychiatry Res 2011;193:101-106.

-47 van Straaten EC, Fazekas F, Rostrup E, Scheltens $\mathrm{P}$, Schmidt R, Pantoni L, Inzitari D, Waldemar G, Erkinjuntti T, Mantyla R, et al: Impact of white matter hyperintensities scoring method on correlations with clinical data: the LADIS study. Stroke 2006;37:836840.

48 Davis Garrett K, Cohen RA, Paul RH, Moser DJ, Malloy PF, Shah P, Haque O: Computermediated measurement and subjective ratings of white matter hyperintensities in vascular dementia: relationships to neuropsychological performance. Clin Neuropsychol 2004; 18:50-62.

49 Pantoni L, Garcia JH: The significance of cerebral white matter abnormalities 100 years after Binswanger's report. A review. Stroke 1995;26:1293-1301.

- 50 Schmidt R, Schmidt H, Haybaeck J, Loitfelder M, Weis S, Cavalieri M, Seiler S, Enzinger C, Ropele S, Erkinjuntti T, et al: Heterogeneity in age-related white matter changes. Acta Neuropathol 2011;122:171185.

51 Schmidt R, Scheltens P, Erkinjuntti T, Pantoni L, Markus HS, Wallin A, Barkhof F, Fazekas F: White matter lesion progression: a surrogate endpoint for trials in cerebral small-vessel disease. Neurology 2004;63: 139-144.

52 Englund E, Brun A, Alling C: White matter changes in dementia of Alzheimer's type. Biochemical and neuropathological correlates. Brain 1988;111:1425-1439. 
53 Wardlaw JM, Sandercock PA, Dennis MS, Starr J: Is breakdown of the blood-brain barrier responsible for lacunar stroke, leukoaraiosis, and dementia? Stroke 2003;34: 806-812.

54 Smith EE, Egorova S, Blacker D, Killiany RJ, Muzikansky A, Dickerson BC, Tanzi RE, Albert MS, Greenberg SM, Guttmann CR: Magnetic resonance imaging white matter hyperintensities and brain volume in the prediction of mild cognitive impairment and dementia. Arch Neurol 2008;65:94-100.

55 Breteler MM, van Swieten JC, Bots ML, Grobbee DE, Claus JJ, van den Hout JH, van Harskamp F, Tanghe HL, de Jong PT, van Gijn J, et al: Cerebral white matter lesions, vascular risk factors, and cognitive function in a population-based study: the Rotterdam Study. Neurology 1994;44:1246-1252.

-56 Wakefield DB, Moscufo N, Guttmann CR, Kuchel GA, Kaplan RF, Pearlson G, Wolfson L: White matter hyperintensities predict functional decline in voiding, mobility, and cognition in older adults. J Am Geriatr Soc 2010;58:275-281.

-57 Chui HC: Subcortical ischemic vascular dementia. Neurol Clin 2007;25:717-740, vi.

-58 Lamar M, Price CC, Libon DJ, Penney DL, Kaplan E, Grossman M, Heilman KM: Alterations in working memory as a function of leukoaraiosis in dementia. Neuropsychologia 2007;45:245-254

59 Schmidt R, Fazekas F, Offenbacher H, Dusek T, Zach E, Reinhart B, Grieshofer P, Freidl W, Eber B, Schumacher M, et al: Neuropsychologic correlates of MRI white matter hyperintensities: a study of 150 normal volunteers. Neurology 1993;43:2490-2494.

60 Ylikoski R, Ylikoski A, Erkinjuntti T, Sulkava $R$, Raininko $R$, Tilvis R: White matter changes in healthy elderly persons correlate with attention and speed of mental processing. Arch Neurol 1993;50:818-824.

-61 Prins ND, van Dijk EJ, den Heijer T, Vermeer SE, Jolles J, Koudstaal PJ, Hofman A, Breteler MM: Cerebral small-vessel disease and decline in information processing speed, executive function and memory. Brain 2005; 128 : 2034-2041.

-62 Tell GS, Lefkowitz DS, Diehr P, Elster AD: Relationship between balance and abnormalities in cerebral magnetic resonance imaging in older adults. Arch Neurol 1998;55: 73-79.

63 Steingart A, Hachinski VC, Lau C, Fox AJ, Diaz F, Cape R, Lee D, Inzitari D, Merskey H: Cognitive and neurologic findings in subjects with diffuse white matter lucencies on computed tomographic scan (leuko-araiosis). Arch Neurol 1987;44:32-35.

-64 Kerber KA, Enrietto JA, Jacobson KM, Baloh RW: Disequilibrium in older people: a prospective study. Neurology 1998;51:574-580.

65 Baloh RW, Ying SH, Jacobson KM: A longitudinal study of gait and balance dysfunction in normal older people. Arch Neurol 2003;60:835-839.
66 Rosano C, Kuller LH, Chung H, Arnold AM, Longstreth WT Jr, Newman AB: Subclinical brain magnetic resonance imaging abnormalities predict physical functional decline in high-functioning older adults. J Am Geriatr Soc 2005;53:649-654.

67 O’Brien JT, Desmond P, Ames D, Schweitzer I, Chiu E, Tress B: Temporal lobe magnetic resonance imaging can differentiate $\mathrm{Alz}$ heimer's disease from normal ageing, depression, vascular dementia and other causes of cognitive impairment. Psychol Med 1997; 27:1267-1275.

68 Godin O, Dufouil C, Maillard P, Delcroix N, Mazoyer B, Crivello F, Alperovitch A, Tzourio $\mathrm{C}$ : White matter lesions as a predictor of depression in the elderly: the 3C-Dijon study. Biol Psychiatry 2008;63:663-669.

69 Pantoni L, Poggesi A, Basile AM, Pracucci G, Barkhof F, Chabriat H, Erkinjuntti T, Ferro JM, Hennerici M, O’Brien J, et al: Leukoaraiosis predicts hidden global functioning impairment in nondisabled older people: the LADIS (Leukoaraiosis and Disability in the Elderly) Study. J Am Geriatr Soc 2006;54: 1095-1101.

70 Baldwin RC, O’Brien J: Vascular basis of lateonset depressive disorder. Br J Psychiatry 2002;180:157-160.

71 O’Brien J, Desmond P, Ames D, Schweitzer I, Harrigan S, Tress B: A magnetic resonance imaging study of white matter lesions in depression and Alzheimer's disease. Br J Psychiatry 1996;168:477-485.

72 Prins ND, van Dijk EJ, den Heijer T, Vermeer SE, Koudstaal PJ, Oudkerk M, Hofman A, Breteler MM: Cerebral white matter lesions and the risk of dementia. Arch Neurol 2004; 61:1531-1534.

73 Leys D, Henon H, Pasquier F: White matter changes and poststroke dementia. Dement Geriatr Cogn Disord 1998;9(suppl 1):25-29.

-74 Jokinen H, Kalska H, Ylikoski R, Madureira S, Verdelho A, van der Flier WM, Scheltens P, Barkhof F, Visser MC, Fazekas F, et al: Longitudinal cognitive decline in subcortical ischemic vascular disease - the LADIS Study. Cerebrovasc Dis 2009;27:384-391.

75 Pantoni L, Basile AM, Pracucci G, Asplund $\mathrm{K}$, Bogousslavsky J, Chabriat $\mathrm{H}$, Erkinjuntti T, Fazekas F, Ferro JM, Hennerici M, et al: Impact of age-related cerebral white matter changes on the transition to disability - the LADIS study: rationale, design and methodology. Neuroepidemiology 2005;24:51-62.

76 Inzitari D, Simoni M, Pracucci G, Poggesi A, Basile AM, Chabriat H, Erkinjuntti T, Fazekas F, Ferro JM, Hennerici M, et al: Risk of rapid global functional decline in elderly patients with severe cerebral age-related white matter changes: the LADIS study. Arch Intern Med 2007;167:81-88.
77 Verdelho A, Madureira S, Moleiro C, Ferro JM, Santos CO, Erkinjuntti T, Pantoni L, Fazekas F, Visser M, Waldemar G, et al: White matter changes and diabetes predict cognitive decline in the elderly: the LADIS study. Neurology 2010;75:160-167.

78 Godin O, Tzourio C, Rouaud O, Zhu Y, Maillard P, Pasquier F, Crivello F, Alperovitch A, Mazoyer B, Dufouil C: Joint effect of white matter lesions and hippocampal volumes on severity of cognitive decline: the 3C-Dijon MRI study. J Alzheimers Dis 2010;20:453463.

79 Alexopoulos GS, Meyers BS, Young RC, Kakuma T, Silbersweig D, Charlson M: Clinically defined vascular depression. Am J Psychiatry 1997;154:562-565.

80 Barnes DE, Alexopoulos GS, Lopez OL, Williamson JD, Yaffe K: Depressive symptoms, vascular disease, and mild cognitive impairment: findings from the Cardiovascular Health Study. Arch Gen Psychiatry 2006;63: 273-279.

81 Naarding P, Schoevers RA, Janzing JG, Jonker C, Koudstaal PJ, Beekman AT: A study on symptom profiles of late-life depression: the influence of vascular, degenerative and inflammatory risk-indicators. J Affect Disord 2005;88:155-162.

82 Krishnan KR, Taylor WD, McQuoid DR, MacFall JR, Payne ME, Provenzale JM, Steffens DC: Clinical characteristics of magnetic resonance imaging-defined subcortical ischemic depression. Biol Psychiatry 2004; 55:390-397.

-83 Lyness JM, Caine ED, Cox C, King DA, Conwell Y, Olivares T: Cerebrovascular risk factors and later-life major depression. Testing a small-vessel brain disease model. Am J Geriatr Psychiatry 1998;6:5-13.

84 Holley C, Murrell SA, Mast BT: Psychosocial and vascular risk factors for depression in the elderly. Am J Geriatr Psychiatry 2006;14: 84-90.

$>85$ Thomas AJ, O’Brien JT, Davis S, Ballard C, Barber R, Kalaria RN, Perry RH: Ischemic basis for deep white matter hyperintensities in major depression: a neuropathological study. Arch Gen Psychiatry 2002;59:785792 .

86 Komaki S, Nagayama H, Ohgami H, Takaki $\mathrm{H}$, Mori H, Akiyoshi J: Prospective study of major depressive disorder with white matter hyperintensity: comparison of patients with and without lacunar infarction. Eur Arch Psychiatry Clin Neurosci 2008;258:160-164.

87 Teodorczuk A, Firbank MJ, Pantoni L, Poggesi A, Erkinjuntti T, Wallin A, Wahlund LO, Scheltens P, Waldemar G, Schrotter G, et al: Relationship between baseline white-matter changes and development of late-life depressive symptoms: 3-year results from the LADIS study. Psychol Med 2010;40:603-610.
Hommet/Mondon/Constans/Beaufils/ Desmidt/Camus/Cottier 
88 Teodorczuk A, O’Brien JT, Firbank MJ, Pantoni L, Poggesi A, Erkinjuntti T, Wallin A, Wahlund LO, Gouw A, Waldemar G, et al: White matter changes and late-life depressive symptoms: longitudinal study. Br J Psychiatry 2007;191:212-217.

-89 Steffens DC, Krishnan KR, Crump C, Burke GL: Cerebrovascular disease and evolution of depressive symptoms in the cardiovascular health study. Stroke 2002;33:1636-1644.

90 Versluis CE, van der Mast RC, van Buchem MA, Bollen EL, Blauw GJ, Eekhof JA, van der Wee NJ, de Craen AJ: Progression of cerebral white matter lesions is not associated with development of depressive symptoms in elderly subjects at risk of cardiovascular disease: the PROSPER Study. Int J Geriatr Psychiatry 2006;21:375-381.

-91 Casanova MF, Starkstein SE, Jellinger KA: Clinicopathological correlates of behavioral and psychological symptoms of dementia. Acta Neuropathol 2011:122:117-135.

-92 Santos M, Kovari E, Hof PR, Gold G, Bouras C, Giannakopoulos P: The impact of vascular burden on late-life depression. Brain Res Rev 2009;62:19-32.

-93 Jellinger KA: Neuropathological analysis of brain lesions in late-onset depression. Neuropathol Appl Neurobiol 2011;37:560-562.

$\$ 94$ Brun A, Englund E: A white matter disorder in dementia of the Alzheimer type: a pathoanatomical study. Ann Neurol 1986;19:253262.

95 Bombois S, Debette S, Delbeuck X, Bruandet A, Lepoittevin S, Delmaire C, Leys D, Pasquier F: Prevalence of subcortical vascular lesions and association with executive function in mild cognitive impairment subtypes. Stroke 2007;38:2595-2597.

-96 Debette S, Bombois S, Bruandet A, Delbeuck X, Lepoittevin S, Delmaire C, Leys D, Pasquier F: Subcortical hyperintensities are associated with cognitive decline in patients with mild cognitive impairment. Stroke 2007;38:2924-2930.

-97 Tullberg M, Fletcher E, DeCarli C, Mungas D, Reed BR, Harvey DJ, Weiner MW, Chui HC, Jagust WJ: White matter lesions impair frontal lobe function regardless of their location. Neurology 2004;63:246-253.

-98 Wolf H, Ecke GM, Bettin S, Dietrich J, Gertz HJ: Do white matter changes contribute to the subsequent development of dementia in patients with mild cognitive impairment? A longitudinal study. Int J Geriatr Psychiatry 2000;15:803-812.

-99 Bombois S, Debette S, Bruandet A, Delbeuck X, Delmaire C, Leys D, Pasquier F: Vascular subcortical hyperintensities predict conversion to vascular and mixed dementia in MCI patients. Stroke 2008;39:2046-2051.
100 Staekenborg SS, Koedam EL, Henneman WJ, Stokman P, Barkhof F, Scheltens P, van der Flier WM: Progression of mild cognitive impairment to dementia: contribution of cerebrovascular disease compared with medial temporal lobe atrophy. Stroke 2009; 40:1269-1274.

101 Silbert LC, Howieson DB, Dodge H, Kaye JA: Cognitive impairment risk: white matter hyperintensity progression matters. Neurology 2009;73:120-125.

102 Jacobs HI, Visser PJ, Van Boxtel MP, Frisoni GB, Tsolaki M, Papapostolou P, Nobili F, Wahlund LO, Minthon L, Frolich L, et al: The association between white matter hyperintensities and executive decline in mild cognitive impairment is network dependent. Neurobiol Aging 2012;33:201. e1-e8.

103 Carmichael O, Schwarz C, Drucker D, Fletcher E, Harvey D, Beckett L, Jack CR, Jr., Weiner M, DeCarli C: Longitudinal changes in white matter disease and cognition in the first year of the Alzheimer disease neuroimaging initiative. Arch Neurol 2010;67:1370-1378.

104 Kumar R, Parslow RA, Jorm AF, Rosenman SJ, Maller J, Meslin C, Anstey KJ, Chris tensen H, Sachdev PS: Clinical and neuroimaging correlates of mild cognitive impairment in a middle-aged community sample: the personality and total health through life 60+ study. Dement Geriatr Cogn Disord 2006;21:44-50.

105 Jagust WJ, Zheng L, Harvey DJ, Mack WJ, Vinters HV, Weiner MW, Ellis WG, Zarow C, Mungas D, Reed BR, et al: Neuropathological basis of magnetic resonance images in aging and dementia. Ann Neurol 2008, 63:72-80

106 Koennecke HC: Cerebral microbleeds on MRI: prevalence, associations, and potential clinical implications. Neurology 2006; 66:165-171.

107 Greenberg SM, Vernooij MW, Cordonnier C, Viswanathan A, Al-Shahi Salman R, Warach S, Launer LJ, Van Buchem MA, Breteler MM: Cerebral microbleeds: a guide to detection and interpretation. Lancet Neurol 2009;8:165-174.

108 Roob G, Fazekas F: Magnetic resonance imaging of cerebral microbleeds. Curr Opin Neurol 2000;13:69-73.

109 Cordonnier C, Al-Shahi Salman R, Wardlaw J: Spontaneous brain microbleeds: systematic review, subgroup analyses and standards for study design and reporting. Brain 2007;130:1988-2003.

110 Yakushiji Y, Nishiyama M, Yakushiji S, Hirotsu T, Uchino A, Nakajima J, Eriguchi M, Nanri Y, Hara M, Horikawa E, et al: Brain microbleeds and global cognitive function in adults without neurological disorder. Stroke 2008;39:3323-3328.
111 Fazekas F, Kleinert R, Roob G, Kleinert G, Kapeller P, Schmidt R, Hartung HP: Histopathologic analysis of foci of signal loss on gradient-echo $\mathrm{T} 2{ }^{*}$-weighted MR images in patients with spontaneous intracerebral hemorrhage: evidence of microangiopathyrelated microbleeds. AJNR Am J Neuroradiol 1999;20:637-642.

112 Tanaka A, Ueno Y, Nakayama Y, Takano K, Takebayashi S: Small chronic hemorrhages and ischemic lesions in association with spontaneous intracerebral hematomas. Stroke 1999;30:1637-1642.

-113 Cordonnier C: Brain microbleeds. Pract Neurol 2010;10:94-100.

-114 Cordonnier C, van der Flier WM, Sluimer JD, Leys D, Barkhof F, Scheltens P: Prevalence and severity of microbleeds in a memory clinic setting. Neurology 2006;66: 1356-1360.

115 Goos JD, Kester MI, Barkhof F, Klein M, Blankenstein MA, Scheltens P, van der Flier WM: Patients with Alzheimer disease with multiple microbleeds: relation with cerebrospinal fluid biomarkers and cognition. Stroke 2009;40:3455-3460.

116 Hanyu H, Tanaka Y, Shimizu S, Takasaki M, Abe K: Cerebral microbleeds in Alzheimer's disease. J Neurol 2003;250:14961497.

117 Kato H, Izumiyama M, Izumiyama K, Takahashi A, Itoyama Y: Silent cerebral microbleeds on T2*-weighted MRI: correlation with stroke subtype, stroke recurrence, and leukoaraiosis. Stroke 2002;33:15361540.

118 Pettersen JA, Sathiyamoorthy G, Gao FQ, Szilagyi G, Nadkarni NK, St George-Hyslop P, Rogaeva E, Black SE: Microbleed topography, leukoaraiosis, and cognition in probable Alzheimer disease from the Sunnybrook dementia study. Arch Neurol 2008;65:790-795.

119 Werring DJ, Frazer DW, Coward LJ, Losseff NA, Watt H, Cipolotti L, Brown MM, Jager HR: Cognitive dysfunction in patients with cerebral microbleeds on T2* -weighted gradient-echo MRI. Brain 2004;127:22652275.

$>120$ Won Seo S, Hwa Lee B, Kim EJ, Chin J, Sun Cho Y, Yoon U, Na DL: Clinical significance of microbleeds in subcortical vascular dementia. Stroke 2007;38:1949-1951.

121 Greenberg SM, Eng JA, Ning M, Smith EE, Rosand J: Hemorrhage burden predicts recurrent intracerebral hemorrhage after lobar hemorrhage. Stroke 2004;35:14151420.

122 Seo WK, Lee JM, Park MH, Park KW, Lee DH: Cerebral microbleeds are independently associated with arterial stiffness in stroke patients. Cerebrovasc Dis 2008;26: 618-623. 
-123 Tang WK, Chen YK, Lu JY, Chu WC, Mok VC, Ungvari GS, Wong KS: Cerebral microbleeds and depression in lacunar stroke. Stroke 2011;42:2443-2446.

-124 Tang WK, Chen YK, Lu JY, Mok VC, Xiang YT, Ungvari GS, Ahuja AT, Wong KS: Microbleeds and post-stroke emotional lability. J Neurol Neurosurg Psychiatry 2009;80: 1082-1086.

- 125 Tang WK, Chen YK, Lu JY, Chu WC, Mok VC, Ungvari GS, Wong KS: Cerebral microbleeds and symptom severity of poststroke depression: a magnetic resonance imaging study. J Affect Disord 2011;129: 354-358.

-126 Kirsch W, McAuley G, Holshouser B, Petersen F, Ayaz M, Vinters HV, Dickson C, Haacke EM, Britt W 3rd, Larseng J, et al: Serial susceptibility weighted MRI measures brain iron and microbleeds in dementia. J Alzheimers Dis 2009;17:599-609.

-127 Ayaz M, Boikov AS, Haacke EM, Kido DK, Kirsch WM: Imaging cerebral microbleeds using susceptibility weighted imaging: one step toward detecting vascular dementia. J Magn Reson Imaging 2010;31:142-148.

-128 Scheltens P, Barkhof F, Valk J, Algra PR, van der Hoop RG, Nauta J, Wolters EC: White matter lesions on magnetic resonance imaging in clinically diagnosed Alzheimer's disease. Evidence for heterogeneity. Brain 1992;115:735-748.

129 Scheltens P, Barkhof F, Leys D, Wolters EC, Ravid R, Kamphorst W: Histopathologic correlates of white matter changes on MRI in Alzheimer's disease and normal aging. Neurology 1995;45:883-888.

-130 Simpson JE, Ince PG, Higham CE, Gelsthorpe $\mathrm{CH}$, Fernando MS, Matthews F, Forster G, O’Brien JT, Barber R, Kalaria RN, et al: Microglial activation in white matter lesions and nonlesional white matter of ageing brains. Neuropathol Appl Neurobiol 2007;33:670-683.

-131 Gouw AA, Seewann A, Vrenken H, van der Flier WM, Rozemuller JM, Barkhof F, Scheltens P, Geurts JJ: Heterogeneity of white matter hyperintensities in Alzheimer's disease: post-mortem quantitative MRI and neuropathology. Brain 2008;131: 3286-3298.

-132 Akiyama H, Barger S, Barnum S, Bradt B, Bauer J, Cole GM, Cooper NR, Eikelenboom P, Emmerling M, Fiebich BL, et al: Inflammation and Alzheimer's disease. Neurobiol Aging 2000;21:383-421.

-133 Chauveau F, Van Camp N, Dolle F, Kuhnast B, Hinnen F, Damont A, Boutin H, James M, Kassiou M, Tavitian B: Comparative evaluation of the translocator protein radioligands ${ }^{11} \mathrm{C}$-DPA-713, ${ }^{18} \mathrm{~F}-\mathrm{DPA}-714$, and ${ }^{11} \mathrm{C}-\mathrm{PK} 11195$ in a rat model of acute neuroinflammation. J Nucl Med 2009;50:468476.
134 Heneka MT, O’Banion MK: Inflammatory processes in Alzheimer's disease. J Neuroimmunol 2007; 184:69-91.

135 Meda L, Cassatella MA, Szendrei GI, Otvos L Jr, Baron P, Villalba M, Ferrari D, Rossi F: Activation of microglial cells by $\beta$-amyloid protein and interferon- $\gamma$. Nature 1995;374: 647-650.

136 Heneka MT, Sastre M, Dumitrescu-Ozimek L, Hanke A, Dewachter I, Kuiperi C, O’Banion K, Klockgether T, Van Leuven F, Landreth GE: Acute treatment with the PPAR $\gamma$ agonist pioglitazone and ibuprofen reduces glial inflammation and $A \beta 1-42$ levels in APPV717I transgenic mice. Brain 2005; 128:1442-1453

137 Nagele RG, D’Andrea MR, Lee H, Venkataraman V, Wang HY: Astrocytes accumulate A $\beta 42$ and give rise to astrocytic amyloid plaques in Alzheimer disease brains. Brain Res 2003;971:197-209.

138 Cagnin A, Kassiou M, Meikle SR, Banati RB: Positron emission tomography imaging of neuroinflammation. Neurotherapeutics 2007;4:443-452.

139 Venneti S, Wiley CA, Kofler J: Imaging microglial activation during neuroinflammation and Alzheimer's disease. J Neuroimmune Pharmacol 2009;4:227-243

140 Clark CM, Schneider JA, Bedell BJ, Beach TG, Bilker WB, Mintun MA, Pontecorvo MJ, Hefti F, Carpenter AP, Flitter ML, et al: Use of florbetapir-PET for imaging $\beta$-amyloid pathology. JAMA 2011;305:275-283.

141 Formichi P, Parnetti L, Radi E, Cevenini G, Dotti MT, Federico A: CSF levels of $\beta$-amyloid 1-42, Tau and phosphorylated Tau protein in CADASIL. Eur J Neurol 2008;15: 1252-1255.

142 Stenset V, Johnsen L, Kocot D, Negaard A, Skinningsrud A, Gulbrandsen P, Wallin A, Fladby T: Associations between white matter lesions, cerebrovascular risk factors, and low CSF A $\beta 42$. Neurology 2006;67: 830-833.

143 Jonsson M, Zetterberg H, van Straaten E, Lind K, Syversen S, Edman A, Blennow K, Rosengren L, Pantoni L, Inzitari D, et al: Cerebrospinal fluid biomarkers of white matter lesions - cross-sectional results from the LADIS study. Eur J Neurol 2010; 17:377-382.

144 Dierksen GA, Skehan ME, Khan MA, Jeng J, Nandigam RN, Becker JA, Kumar A, Nea KL, Betensky RA, Frosch MP, et al: Spatial relation between microbleeds and amyloid deposits in amyloid angiopathy. Ann Neurol 2010;68:545-548.

145 Takahashi W, Takagi S, Ide M, Shohtsu A, Shinohara Y: Global reduction of cerebral glucose metabolism in persons with symptomatic as well as asymptomatic lacunar infarction. Keio J Med 2000;49(suppl 1):A98A100.
146 Kochunov P, Ramage AE, Lancaster JL, Robin DA, Narayana S, Coyle T, Royall DR, Fox P: Loss of cerebral white matter structural integrity tracks the gray matter metabolic decline in normal aging. Neuroimage 2009;45:17-28.

147 van der Flier WM, van Straaten EC, Barkhof F, Ferro JM, Pantoni L, Basile AM, Inzitari D, Erkinjuntti T, Wahlund LO, Rostrup E, et al: Medial temporal lobe atrophy and white matter hyperintensities are associated with mild cognitive deficits in nondisabled elderly people: the LADIS study. J Neurol Neurosurg Psychiatry 2005;76: 1497-1500.

148 Nicoll JA, Yamada M, Frackowiak J, MazurKolecka B, Weller RO: Cerebral amyloid angiopathy plays a direct role in the pathogenesis of Alzheimer's disease. Pro-CAA position statement. Neurobiol Aging 2004; 25:589-597; discussion 603-584.

149 Kantarci K, Weigand SD, Przybelski SA, Shiung MM, Whitwell JL, Negash S, Knopman DS, Boeve BF, O'Brien PC, Petersen $\mathrm{RC}$, et al: Risk of dementia in MCI: combined effect of cerebrovascular disease, volumetric MRI, and 1H MRS. Neurology 2009;72:1519-1525

150 Chowdhury MH, Nagai A, Bokura H, Nakamura E, Kobayashi S, Yamaguchi S: Agerelated changes in white matter lesions, hippocampal atrophy, and cerebral microbleeds in healthy subjects without major cerebrovascular risk factors. J Stroke Cerebrovasc Dis 2011;20:302-309.

151 Masuda J, Tanaka K, Ueda K, Omae T: Autopsy study of incidence and distribution of cerebral amyloid angiopathy in Hisayama, Japan. Stroke 1988;19:205-210.

152 Frisoni GB, Galluzzi S, Pantoni L, Filippi $\mathrm{M}$ : The effect of white matter lesions on cognition in the elderly - small but detectable. Nat Clin Pract Neurol 2007;3:620-627.

153 Cordonnier C, van der Flier WM: Brain microbleeds and Alzheimer's disease: innocent observation or key player? Brain 2011; 134:335-344.

154 Haacke EM, Xu Y, Cheng YC, Reichenbach JR: Susceptibility weighted imaging (SWI). Magn Reson Med 2004;52:612-618.

155 Werring DJ, Gregoire SM, Cipolotti L: Cerebral microbleeds and vascular cognitive impairment. J Neurol Sci 2010;299:131-135.

156 Lee DY, Fletcher E, Martinez O, Ortega M, Zozulya N, Kim J, Tran J, Buonocore M, Carmichael O, DeCarli C: Regional pattern of white matter microstructural changes in normal aging, MCI, and AD. Neurology 2009;73:1722-1728. 